\title{
MEMBANGUN APLIKASI TRANSAKSI PENJUALAN PADA UD TANI JAYA CAKUNG
}

\author{
Hendar Suhendar ${ }^{1}$, Dyah Rhetno Wardhani ${ }^{2}$, Sepni Yanti ${ }^{3}$ \\ ${ }^{1,2,3}$ Teknik Informatika, Fakultas Teknik dan Ilmu Komputer, Universitas Indraprasta PGRI Jakarta \\ Jalan Raya Tengah No 80, Kelurahan Gedong, Pasar Rebo, Jakarta Timur \\ 15shendarisreborn48@gmail.com, ${ }^{2}$ dyahrhetno@gmail.com, ${ }^{3}$ sepniyanti@gmail.com
}

\begin{abstract}
ABSTRAK
Permasalahan yang terdapat pada UD Tani Jaya Cakung adalah terjadinya kesalahan dalam pencatatan pemasukan dan pengeluaran barang di UD. Tani Jaya Cakung sehingga informasi stok barang sering tidak tepat karena masih dihitung secara manual sehingga transaksi penjualan yang dilakukan dengan menggunakan buku besar dalam setiap pencatatannya, sehingga sering terjadi kesalahan-kesalahan yang akan menyebabkan kerugian dan pembuatan laporan kepada pemilik masih membutuhkan banyak waktu sehingga tidak efisien. Tujuan merancang suatu sistem informasi penjualan ini dengan tujuan untuk memudahkan admin dalam memproses pengolahan data yang ada saat ini. Perangkat aplikasi yang telah dibuat dengan bahasa pemrograman Java NetBeans 8.0.2 dan penyimpanan data pada database MySQL dapat memberikan kelancaran dalam proses menginput dan penyimpanan data-data serta laporan-laporan yang diberikan kepada pemilik toko. Dengan menggunakan metode pengembangan sistem yaitu Waterfall dalam penelitian ini adalah dengan tahapan-tahapan seperti rekayasa sistem, analisis, desain, coding, testing, dan maintenance. Hasil dari penelitian ini menciptakan suatu sistem informasi penjualan secara terkomputerisasi sehingga menghasilkan laporan yang tersimpan dengan baik dan memberikan hasil secara cepat dan akurat.
\end{abstract}

Kata Kunci: Aplikasi, Penjualan, Desktop

\section{ABSTRACT}

The problem found at UD Tani Jaya Cakung is the occurrence of errors in recording the entry and exit of goods at UD. Tani Jaya Cakung so that inventory information is often inaccurate because it is still calculated manually so that sales transactions are carried out using a ledger in each recording, so that errors often occur that will cause losses and reporting to the owner still takes a lot of time so it is not efficient. The purpose of designing a sales information system is to make it easier for admins to process the current data processing. Applications that have been made with the Java NetBeans 8.0.2 programming language and data storage in the MYSQL database can provide smooth processing of input and storage of data and reports provided to shop owners. By using the system development method, namely Waterfall, in this research, the stages are systems engineering, analysis, design, coding, testing, and maintenance. The results of this study create a computerized sales information system so as to produce reports that are stored properly and provide results quickly and accurately.

Key Word: Application, Selling, Desktop

\section{PENDAHULUAN}

Seiring dengan perkembangan teknologi informasi, kemajuan teknologi kian bertambah pesat, terutama dalam bidang komputer. Kemajuan teknologi komputer sekarang ini dapat digunakan sebagai alat bantu dalam mengelolah data sudah banyak dimanfaatkan bagi setiap orang atau instansi yang memerlukan (Nurhayati, Josi, \& Hutagalung, 2018). Banyak perusahaan besar, menengah, kecil, bahkan untuk kalangan para pebisnis yang bergerak pada persediaan obat pertanian yang sudah mulai mempergunakan komputer dalam menunjang usahanya, bahkan sekarang komputer memegang peranan yang sangat penting untuk menentukan maju atau mundurnya perusahaan tersebut. Hal ini disebabkan karena kecepatan, keakuratan dan kelengkapan dalam mengelolah data yang dibutuhkan oleh perusahaan (Hariyanto, 2016).

Dalam aktifitasnya, UD. Tani Jaya Cakung ini merupakan sebuah perusahaan yang bergerak dibidang persediaan dan penjualan obat pertanian. Namun dalam melakukan aktifitas pekerjaan UD. Tani Jaya Cakung masih menggunakan metode penulisan data yang manual, misalnya saja 
penyimpanan data yang dilakukan selama ini masih dalam bentuk kertas yang disimpan, hal ini menyebabkan lamanya waktu yang di butuhkan untuk melakukan pencarian data, dan mudah hilang ataupun rusak, sehingga pembuatan laporan menjadi tidak tepat dan tidak akurat.

Pada UD. Tani Jaya Cakung banyak data-data obat pertanian, data transaksi, dan lainnya yang sulit untuk dihafal satu persatu (Ariyati, 2016). Pengolahan data pelanggan pada perusahaan pun kurang lengkap karena masih menggunakan sistem manual, sehingga pelayanan tidak menjadi efisien dan membutuhkan waktu lebih lama. Kendala lain yang sering terjadi pada perusahaan ini adalah stok obat yang sulit diketahui dengan cepat, hal ini terjadi karena tidak teraturnya pencatatan obat yang masuk maupun obat yang keluar. Oleh sebab itu, dibutuhkan sebuah sistem yang dapat mendata daftar-daftar data tersebut (Hasti, Si, Setiadi, \& Kom, 2015).

Perbaikan yang akan dilakukan yaitu membuat sistem pencatatan yang manual dengan menggunakan sistem berbasis komputer, baik dari segi pendataan barang persediaan, pencatatan data transaksi penjualan, proses pembuatan laporan dan yang berkaitan dengan aktifitas pada UD. Tani Jaya Cakung. Dengan adanya sebuah aplikasi sistem informasi pengolahan data yang akan dibuat ini, maka sistem informasi perusahaan akan dapat dikelola dengan lebih baik dengan adanya kuitansi transaksi penjualan dan adanya form return pembelian jika ada barang yang rusak ataupun tidak berfungsi dari pihak supplier (Nasution \& Baidawi, 2016).

Dengan permasalahan tersebut, perlu ada nya suatu sistem yang terkomputerisasi dalam penyelesaiannya. Sistem adalah sekelompok unsur yang erat hubungannya satu dengan yang lain, yang berfungsi bersama-sama untuk mencapai tujuan (Sutabri, 2012). Sistem merupakan suatu kumpulan dari komponenkomponen yang membentuk satu kesatuan (Tyoso, 2016). Pembangunan sistem adalah sekumpulan aktivitas yang menggambarkan secara rinci bagaimana sistem akan berjalan. Hal itu bertujuan untuk menghasilkan produk perangkat lunak yang sesuai dengan kebutuhan user (Satzinger, J. W., Jackson, R. B., Burd, n.d.).

Diharapkan dengan adanya suatu sistem informasi dapat menangani permasalahan yang ada di perusahaan tersebut. Sistem adalah setiap sesuatu terdiri dari obyek-obyek, atau unsur-unsur, atau komponen-komponen yang bertata kaitan dan bertata hubungan satu sama lain, sedemikian rupa sehingga unsur-unsur tersebut merupakan satu kesatuan pemrosesan atau pengolahan yang tertentu. (Prasojo, 2011)

Aplikasi ini dapat memudahkan pekerjaan Admin dalam melaksanakan pembuatan laporan dan dapat memudahkan toko dalam memproses data penjualan pada UD Tani Jaya Cakung.

\section{METODE PENELITIAN}

Peneliti menggunakan metode Research and Development dalam penyelesaian penelitian ini. (Sugiyono, 2016).

Adapun metode pengumpulan data yang dilakukan oleh penulis untuk mendapatkan data-data serta informasi untuk mendukung penyempurnaan hasil dari penelitian ini antara lain:

1. Studi Lapangan

Studi lapangan ini penulis lakukan untuk melihat langsung terhadap penerapan sistem aplikasi penjualan pada UD. Tani Jaya Cakung. Dalam studi lapangan ini dipergunakan teknik pengumpulan data antara lain dengan cara:

a. Observasi

Penulis mempelajari dan mengamati proses-proses yang terdapat pada UD. Tani Jaya Cakung yang beralamat di Jl. Satria No.41, RT.6/RW.3, Ujung Menteng, Kec. Cakung, Kota Jakarta Timur, Daerah Khusus Ibukota Jakarta 13960. Pada bulan Maret 2021 sampai dengan bulan Juli 2021, prosesnya antara lain:

1) Proses Penjualan

Penulis mengamati proses penjualan pada UD. Tani Jaya Cakung mulai dari kedatangan pelanggan sampai dengan 
proses penjualan di UD. Tani Jaya Cakung.

2) Proses Stok Barang Penulis mengamati proses stok barang yang ada di UD. Tani Jaya Cakung.

3) Proses Pembuatan Laporan Penulis mengamati proses pembuatan laporan yang dilakukan oleh admin dan bagian gudang, mulai dari pengecekan laporan sampai dengan cetak laporan.

\section{b. Interview (wawancara)}

Penulis melakukan wawancara kepada pemilik UD. Tani Jaya Cakung yaitu Bapak Tono dan admin tentang proses penjualan, hingga proses pembuatan laporan. Hasil wawancara dengan Bapak Tono sebagai pemilik UD. Tani Jaya diperoleh informasi bahwa proses penjualan saat ini masih manual menggunakan buku besar dan proses transaksi nya masih belum efisien yang dimana kuitansi penjualan nya masih ditulis secara manual tidak terkomputerisasi.

\section{HASIL DAN PEMBAHASAN Analisa Permasalahan}

Pada sistem pengolahan data transaksi penjualan yang manual ini ternyata mempunyai banyak kelemahan, antara lain tingginya tingkat kesalahan manusia (human error) sehingga sering terjadi adanya salah perhitungan pada pembuatan laporan persediaan obat pertanian maupun penjualan obat pertanian. Begitu juga pada proses pencatatan data yang dilakukan secara manual membutuhkan waktu yang cukup lama dalam pengerjaannya. Permasalahan diatas menyebabkan pendapatan dan kinerja perusahaan relatif menurun menyebabkan sering terjadinya permasalahan karena kurang akuratnya data yang akan dijadikan laporan. Itu semua dikarenakan sistem yang dikerjakan masih banyak kekurangannya.

Dari permasalahan diatas penulis mengambil kesimpulan atas permasalahan yang ada diantaranya:

1. Penulisan data obat pertanian, data pelanggan, data pesanan masih dilakukan secara manual.

2. Proses pendataaan secara manual memerlukan waktu yang lama dalam proses pencarian data kembali jika salah satu data dibutuhkan sewaktu-waktu.

3. Pembuatan laporan yang dilakukan secara manual memungkinkan terjadinya kesalahan yang memerlukan waktu yang lama dalam mengubahnya.

\section{Alternatif Penyelesaian Masalah}

Berdasarkan analisa sistem yang sedang berjalan saat ini, dapat di lihat kelemahan-kelemahan dan pokok permasalahan yang terdapat pada sistem persediaan obat pertanian yang sedang berjalan. Maka disarankan beberapa alternatif permasalahan, yaitu:

1. Agar tidak terjadi keterlambatan didalam proses pengerjaan dan informasi, sebaiknya dikoordinasikan dengan baik dan terkomputerisasi dengan benar antara subsistem yang satu dengan yang lainnya, UD. Tani Jaya sebaiknya membuat rancangan sistem yang dapat meringankan dalam mengerjakan, mengumpulkan dan mengecek data-data khususnya pada pengolahan data obat pertanian serta transaksi penjualan dan pembuatan laporan.

2. File ataupun data yang sudah dikerjakan sebaiknya disimpan ke Hardisk atau alat penyimpanan data lain dan sebaiknya dibuat backupnya jika saat terjadi kesalahan kita masih memiliki cadangan file ataupun datadatanya.

3. Alangkah baiknya bila komputer yang digunakan untuk memproses data di upgrade, sehingga pemrosesan data tersebut dapat dilakukan lebih baik, cepat (menghemat waktu) dan tepat. Dengan dibuatnya sistem pengolahan data obat pertanian dengan sistem terkomputerisasi ini, diharapkan dapat mempermudah proses pengerjaan dan pengecekan data khususnya pada proses pembuatan laporan dan pengolahan data obat pertanian serta transaksi penjualan. 


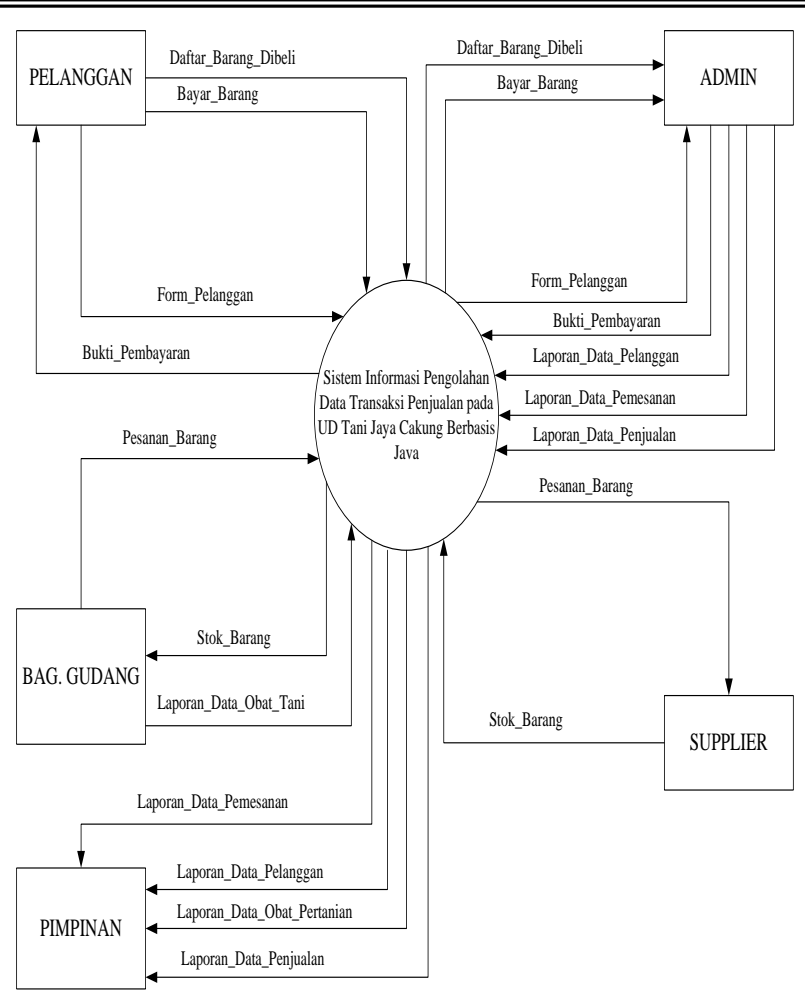

Gambar 1. Diagram Konteks

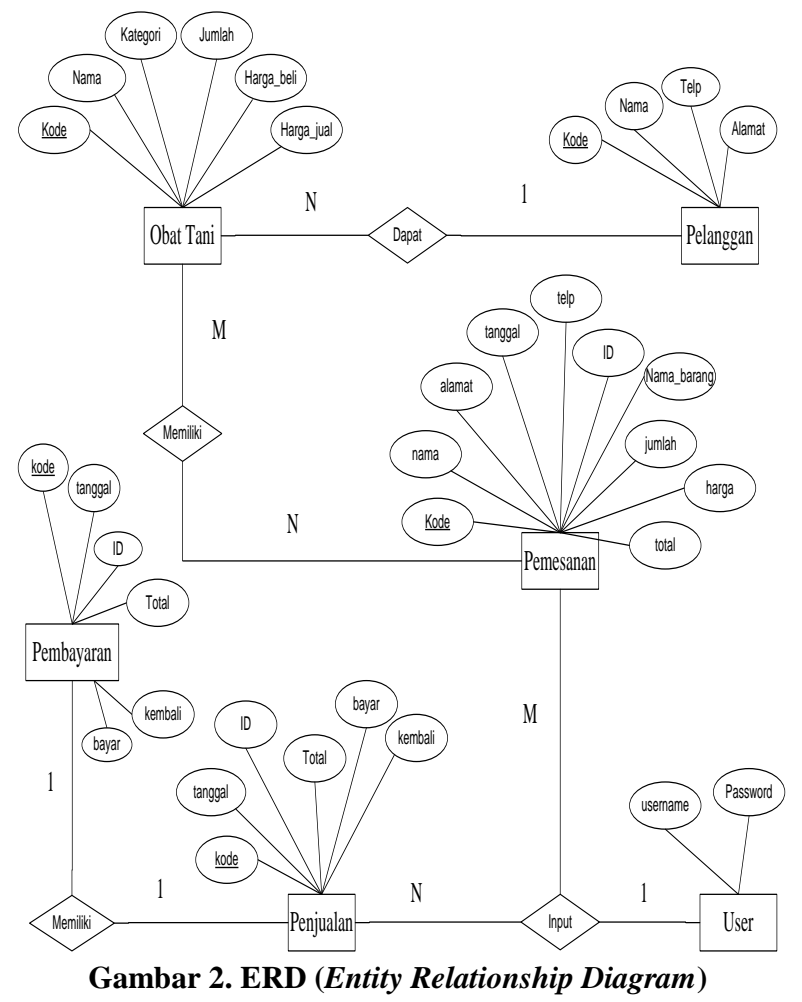

Berikut adalah tampilan layar dan hasil pengujian pada software program yang telah di buat dengan bahasa pemrograman Java.

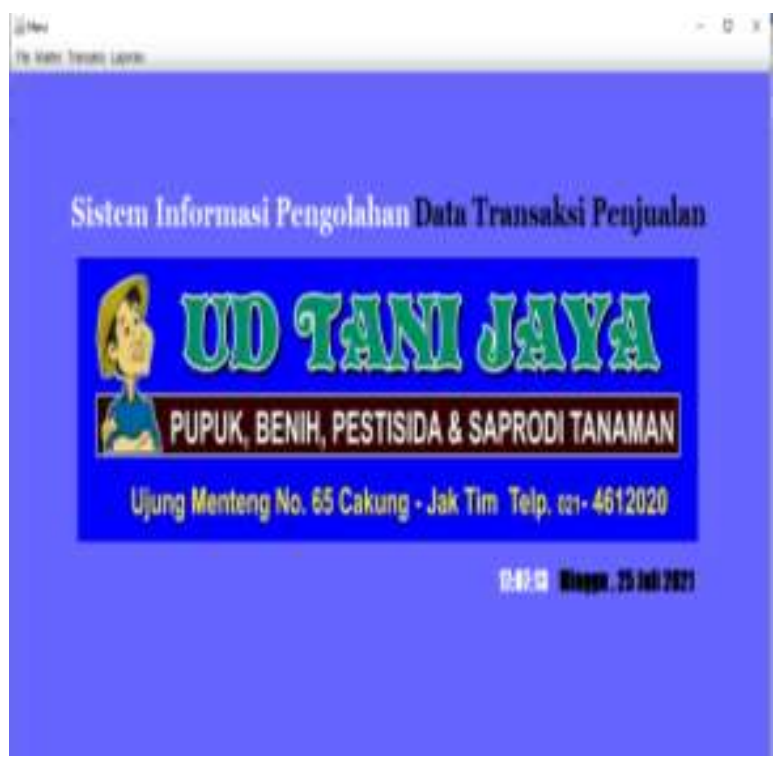

Gambar 3. Form Menu Utama

Layar di atas menampilkan tampilan menu Tampilan Sistem Pengolahan Data Transaksi Penjualan pada UD. Tani Jaya Cakung. Pada layar utama tersedia menubar yang terdiri dari menu Akses yang digunakan pada saat pengguna ingin login atau exit dari aplikasi, menu Berkas yang digunakan untuk memasukkan data yang berkaitan dengan data obat, data pemesanan dan data penjualan. Kemudian menu laporan untuk mencetak semua laporan data obat, data pelanggan, data pemesanan dan data penjualan.

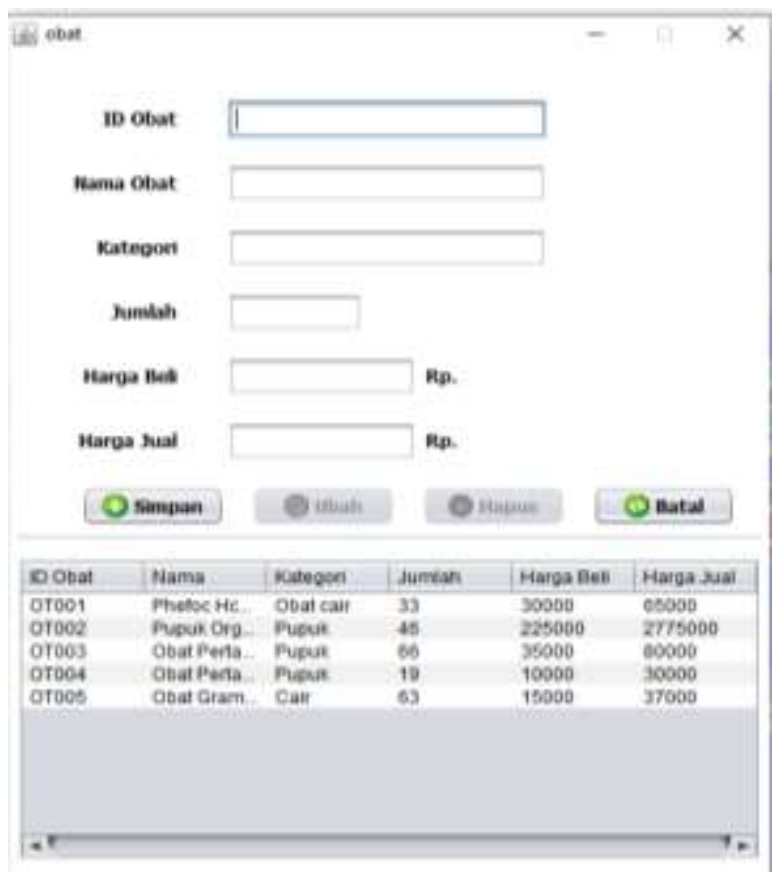

Gambar 4. Form Data Obat Tani 
Layar di atas menampilkan tampilan form data obat. Pada layar form data obat untuk menginput data obat yang terdiri dari ID Obat, Nama Obat, Kategori, Jumlah, Harga Beli, dan Harga Jual.

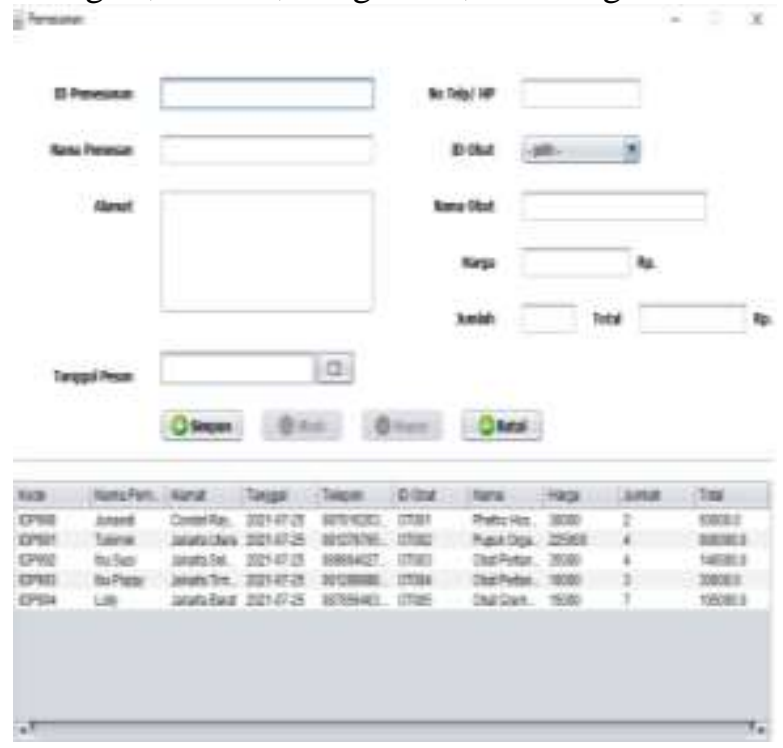

Gambar 5. Form Data Pemesanan

Layar di atas menampilkan tampilan form data pemesanan. Pada layar form data pemesanan untuk menginput data pemesanan yang terdiri dari ID Pemesanan, Nama Pemesan, Alamat, Tanggal Pesan, No Telp, ID Obat, Harga, Jumlah dan Total.

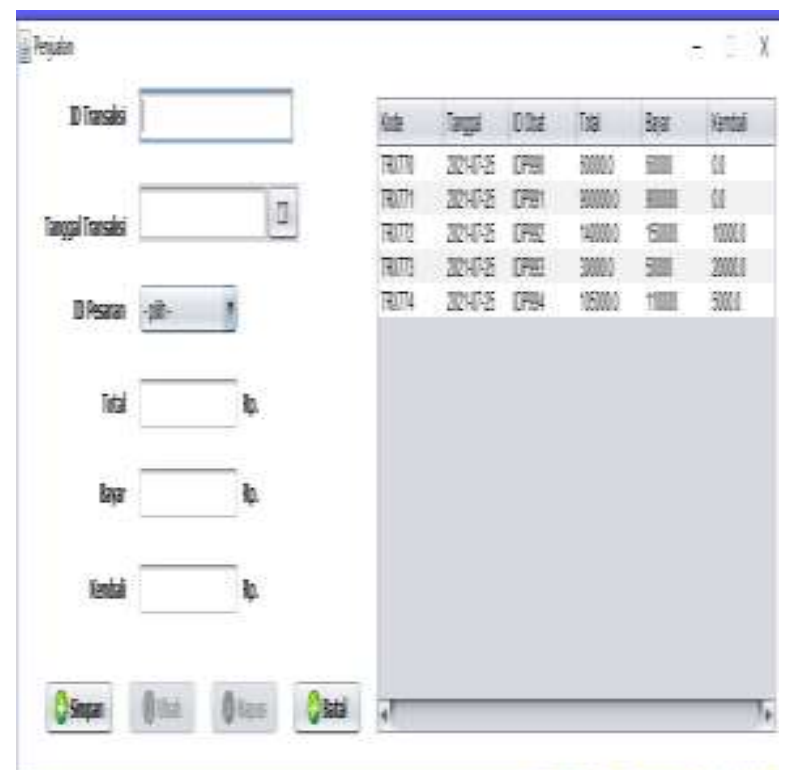

Gambar 6. Data Form Data Transaksi Penjualan

Layar di atas menampilkan tampilan form data penjualan. Pada layar form data penjualan untuk menginput data penjualan yang terdiri dari ID Transaksi, Tgl Transaksi, ID Pesanan, Total, Bayar dan Kembali.

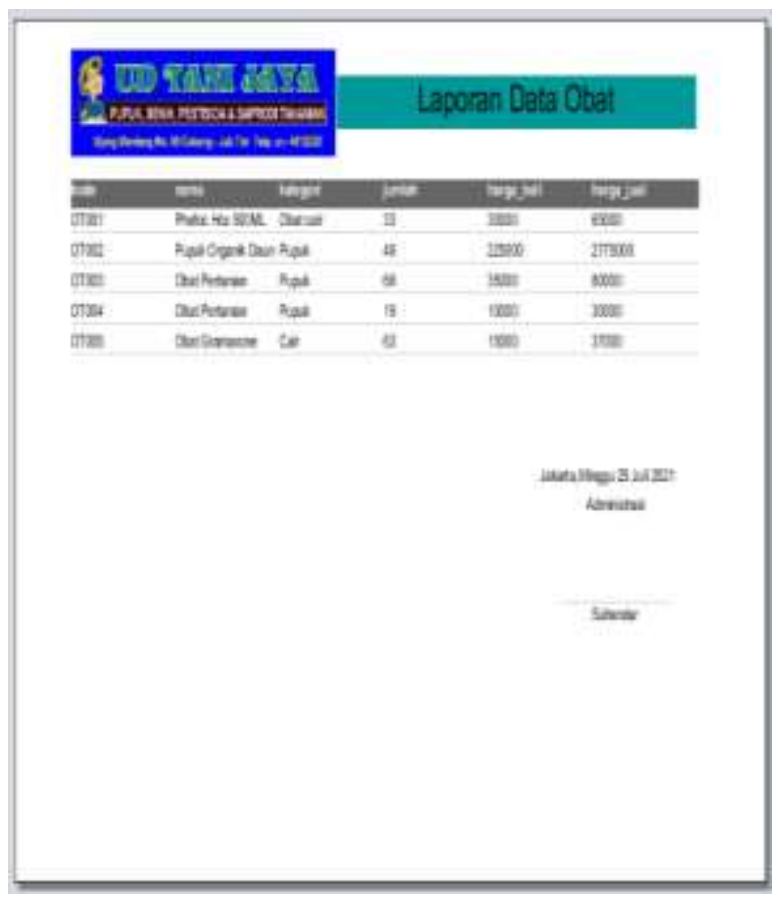

Gambar 7. Laporan Data Obat Tani

Layar di atas menampilkan tampilan form laporan data obat. Pada layar form laporan data obat terdapat informasi data obat yang terdiri dari ID Obat, Nama Obat, Kategori, Jumlah, Harga Beli, dan Harga Jual.

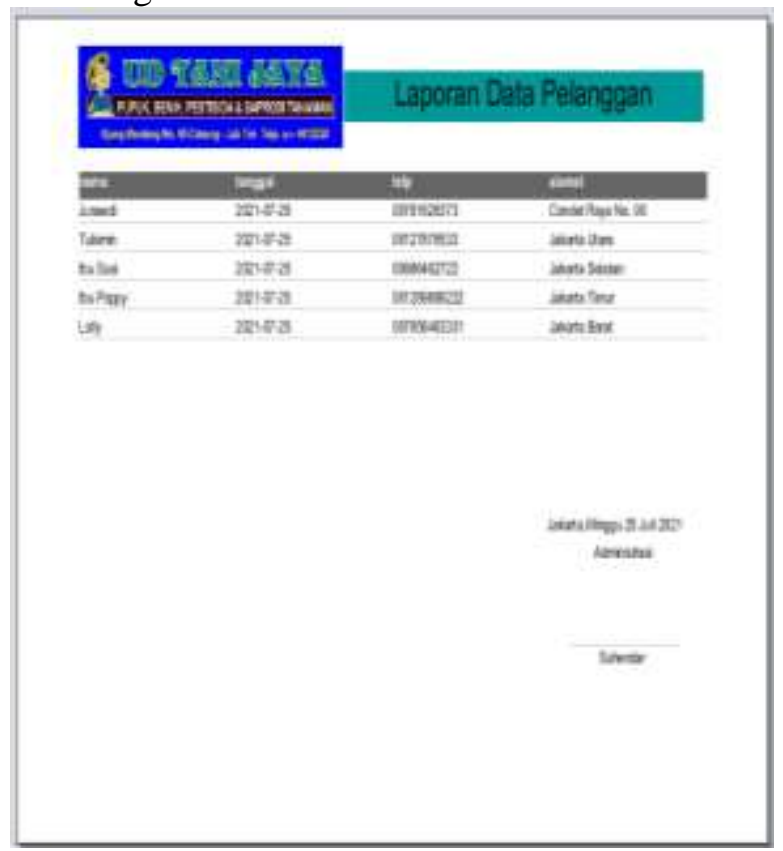

Gambar 8. Laporan Data Pelanggan

617 | Membangun Aplikasi Transaksi Penjualan pada UD Tani Jaya Cakung 
Layar di atas menampilkan tampilan form laporan data pelanggan. Pada layar form laporan data pelanggan terdapat informasi data pelanggan yang terdiri dari Nama, No Telp dan Alamat.

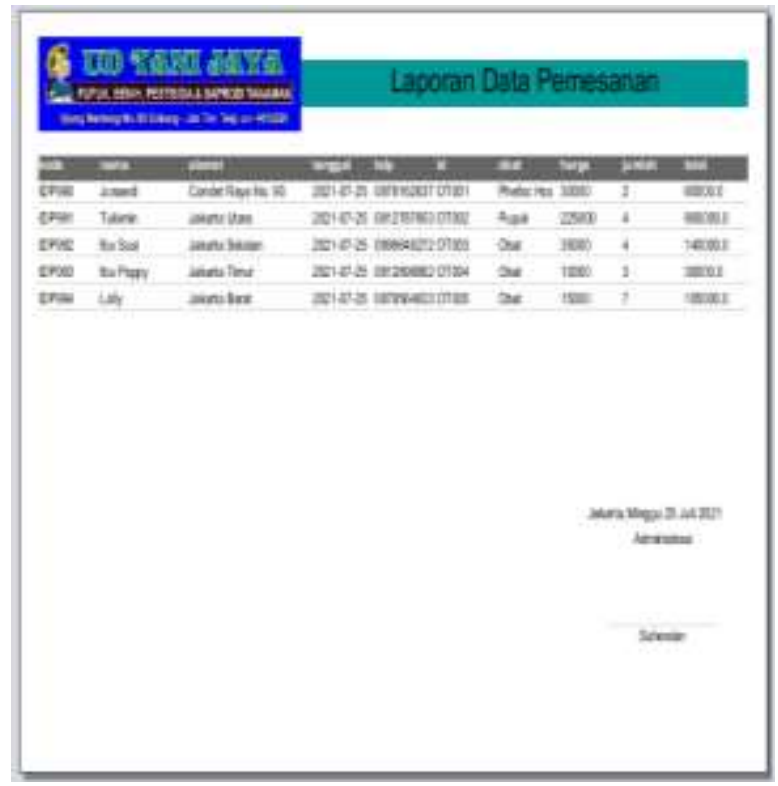

Gambar 9. Laporan Data Pemesanan

Layar di atas menampilkan tampilan form laporan data pemesanan. Pada layar form laporan data pemesanan terdapat informasi data pemesanan yang terdiri dari ID Pemesanan, Nama Pemesan, Alamat, Tanggal Pesan, No Telp, ID Obat, Harga, Jumlah dan Total.

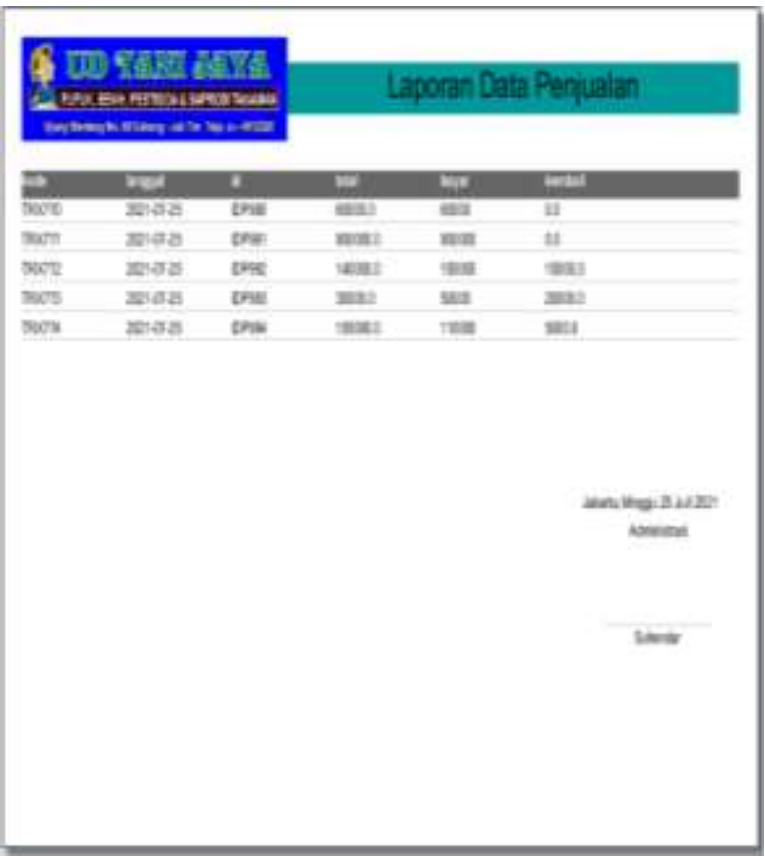

Gambar 10. Laporan Transaksi Penjualan
Layar di atas menampilkan tampilan form laporan data penjualan. Pada layar form laporan data penjualan terdapat informasi data penjualan yang terdiri dari ID Transaksi, Tgl Transaksi, ID Pesanan, Total, Bayar dan Kembali.

\section{SIMPULAN DAN SARAN}

Sistem informasi berbasis Java NetBeans dan penyimpanan data pada database MySQL dapat memperlancar kinerja dalam proses pengolahan data obat pertanian dan transaksi penjualan di UD. Tani Jaya. Sehingga dapat menghasilkan laporan yang akurat dan efektif karena prosesnya sudah terkomputerisasi. Sistem ini pun mudah digunakan, pegawai dapat secara cepat tanpa harus membutuhkan waktu yang banyak serta media penyimpanan yang sangat banyak dalam menginput data dan tanpa sulit untuk mencari data yang diperlukan.

Sarannya adalah untuk periode tertentu perlu adanya pengecekan kembali akan sistem yang diusulkan untuk menjaga segala kemungkinan timbulnya kelemahan sistem dari sistem yang penulis buat.

\section{DAFTAR PUSTAKA}

Ariyati, I. (2016). Sistem Informasi Penjualan Obat Herbal secara Online. Information Management for Educators and Professionals.

Hariyanto, D. (2016). Rancang Bangun Sistem Informasi Pembelian dan Penjualan Barang Berbasis Website ( Studi Kasus : CV . Samdhika Elektronik Depok ). Swabumi, IV(2), 152-166.

Hasti, N., Si, S., Setiadi, D., \& Kom, S. (2015). SISTEM INFORMASI PENJUALAN DAN PEMBELIAN OBAT (Studi Kasus: Apotek Emulinda Bandung) Novrini Hasti, S.Si, MT dan Dani Setiadi, S.Kom. Jurnal Teknologi Dan Informasi (JATI).

Nasution, A., \& Baidawi, T. (2016). Sistem Informasi Penjualan Obat Berbasis Web pada Apotek Perwira Jaya Bekasi. Informatics for Educators and Professionals.

Nurhayati, A. N., Josi, A., \& Hutagalung, N. A. (2018). Rancang Bangun Aplikasi Penjualan Dan Pembelian Barang Pada Koperasi Kartika Samara Grawira Prabumulih. Jurnal Teknologi Dan https://doi.org/10.34010/jati.v7i2.490 Informasi.

Prasojo, M. (2011). Pengantar Sistem Informasi

618 | Membangun Aplikasi Transaksi Penjualan pada UD Tani Jaya Cakung 
Manajemen bandung: CV. Remadja Karya.

Satzinger, J. W., Jackson, R. B., Burd, S. D. (n.d.). System Analysis and Design in A Changing World. USA: Cengage Learning.

Sugiyono. (2016). Metode Penelitian Kuantitatif, Kualitatif dan R\&D. Bandung: PT Alfabet.

Sutabri, T. (2012). Analisis Sistem Informasi. Yogyakarta: Andi.

Tyoso, J. S. P. (2016). Sistem Informasi Manajemen. Yogyakarta: DeePublish. 